\title{
Modeling of Thermophilic Anaerobic Digestion of Municipal Sludge Waste using Anaerobic Digestion Model No. 1 (ADM1)
}

\author{
Taekjun Lee, Young Haeng Lee \\ Center for Water Resource Cycle \\ Korea Institute of Science and Technology \\ Seoul, South Korea
}

Received: January 18, 2021 Revised: February 15, 2021. Accepted: March 3, 2021. Published: March 24, 2021.

\begin{abstract}
Anaerobic digestion model no. 1 (ADM1) model of international water association was applied to a lab-scale thermophilic anaerobic digestion process for the treatment of activated sludge wastes originating from a municipal wastewater treatment plant. The aim of the present study is to compare the results obtained from the simulation with the experimental values. The simulated results showed a good fit for cumulative produced methane gas volume and the concentration profile of total volatile fatty acids (VFAs).
\end{abstract}

Keywords-anaerobic digestion; ADM1; thermophilic; methane gas; municipal sludge wastes

\section{INTRODUCTION}

Anaerobic digestion has been worldwide used for the treatment of numerous types of organic wastes [1]. Anaerobic digestion of the municipal sludge wastes under mesophilic or thermophilic conditions can contribute efficiently in organic waste reduction and biogas production [2]. Because of the importance of anaerobic digestion as an organic waste treatment process, the anaerobic digestion model no. 1 (ADM1) was developed by an international water association (IWA) specialist group [3, 4, 5, 6, 7]. Its main feature is the consideration of the main steps of anaerobic digestion process that are disintegration (non-biological step), hydrolysis, acidogenesis, acetogenesis, and the methanogenesis with seven different microbial groups $[6,8]$.

In the present study, the ADM1 was applied for the simulation of a dynamic behavior of a lab-scale thermophilic anaerobic digestion process which treated municipal sludge wastes.

\section{METHODS}

\section{A. Anaerobic digestion model no.1 (ADM1)}

The ADM1 model developed by the IWA group with the objective to build a full mathematical model based intimately on the phenomenological model was used in order to simulate thermophilic anaerobic digestion process.
The ADM1 model includes, as a first step, the disintegration of organic solid complexes (non-biological step) into carbohydrates, lipids, proteins and inert materials (soluble and particulate inert). The second step is the hydrolysis process of the disintegration products under an enzymatic action to produce sugars, amino acids and long chain fatty acids (LCFA), successively. Then, amino acids and sugars are fermented to produce VFAs, hydrogen and carbon dioxide gas (acidogenesis). Then LCFA, propionic acid, butyric acid and valeric acid are anaerobically biotransformed into acetic acid, carbon dioxide and hydrogen gas (acetogenesis). Finally, methane gas can be produced through two paths: the first one is based on acetate whereas the second one is through the reduction of carbon dioxide by molecular hydrogen.

\section{B. Reactor and experimental monitoring}

As mentioned above, experimental data were obtained from the monitoring of an anaerobic digestion of municipal sludge wastes carried out in the lab-scale batch digester (total liquid volume of $10 \mathrm{~L}$, total headspace volume of $2.3 \mathrm{~L}$ ) which was operated under thermophilic conditions $\left(54 \pm 1^{\circ} \mathrm{C}\right)$ at an organic loading of $10.7 \mathrm{gCOD} / \mathrm{L}_{\text {reactor }}$.

During the operation period, the digestion process was monitored by analyzing $\mathrm{pH}$, total solids (TS) and volatile solids (VS), chemical oxygen demand (COD), volatile fatty acids (VFAs), biogas volume produced, biogas composition $\left(\mathrm{CH}_{4}\right.$, $\mathrm{CO}_{2}$, and $\mathrm{H}_{2}$ ) [9].

\section{RESULTS AND DISCUSSION}

\section{A. Characterization of municipal sludge waste}

The lab-scale batch thermophilic anaerobic digestion reactor was monitored for around 2 months. Typical characteristics of municipal sludge waste were $37 \mathrm{gTS} / \mathrm{L}$, $\mathrm{VS} / \mathrm{TS}$ ratio of $74 \%, 49 \mathrm{gTCOD} / \mathrm{L}$, and VFAs of $1.6 \mathrm{gCOD} / \mathrm{L}$. The substrate was characterized according to the ADM1. Therefore, the model input data were calculated on the basis of characteristics of municipal sludge waste. 


\section{B. Estimation of kinetic parameters}

Kinetic parameters concerning the disintegration and the hydrolysis reactions were first estimated by experimental batch study. The observed kinetic rate constants were 0.8 and $1.6 \mathrm{~d}^{-1}$ for disintegration and hydrolysis reactions, respectively (see Table 1). All values of kinetics and stoichiometry constants were then maintained as in the ADM1 model.

\section{Modeling of reactor performance}

After the estimation of the kinetic rate constants of disintegration and hydrolysis reactions, the obtained experimental data of acetic acid concentration, total VFAs concentration, and cumulative produced methane volume were used for kinetic parameters estimation (see Fig. 1) using the Simplex minimization algorithm [10]. The values of the kinetic parameters involved in the uptake rates of the VFAs, estimated after the model fitting are listed in Table 4. They are also compared with the ADM1 parameter values suggested in the scientific and technical report of ADM1 which applied the model in the case of the anaerobic digestion of sludge waste [4].

TABLE I. ESTIMATED VALUES OF KINETIC PARAMETERS

\begin{tabular}{|c|l|c|c|}
\hline $\begin{array}{c}\text { Kinetic } \\
\text { parameters }\end{array}$ & \multicolumn{1}{|c|}{ Description (unit) } & $\begin{array}{c}\text { Default } \\
\text { values in } \\
\text { ADMI }\end{array}$ & $\begin{array}{c}\text { Estimated } \\
\text { values } \\
\text { (this study) }\end{array}$ \\
\hline $\mathrm{K}_{\mathrm{dis}}$ & $\begin{array}{l}\text { Composites disintegration rate } \\
\left(\mathrm{d}^{-1}\right)\end{array}$ & 0.5 & 0.8 \\
\hline $\mathrm{K}_{\mathrm{hyd}}$ & Hydrolysis rate $\left(\mathrm{d}^{-1}\right)$ & 10 & 1.6 \\
\hline $\mathrm{k}_{\mathrm{m} \_ \text {pro }}$ & Propionate uptake rate $\left(\mathrm{d}^{-1}\right)$ & 13 & 17 \\
\hline $\mathrm{K}_{\mathrm{s} \_ \text {pro }}$ & $\begin{array}{l}\text { Half saturation coefficient for } \\
\text { propionate uptake }\left(\mathrm{kgCOD} / \mathrm{m}^{3}\right)\end{array}$ & 100 & 92 \\
\hline $\mathrm{K}_{\mathrm{m} \_ \text {ac }}$ & Acetate uptake rate $\left(\mathrm{d}^{-1}\right)$ & 8 & 4.7 \\
\hline $\mathrm{K}_{\mathrm{s} \_ \text {ac }}$ & $\begin{array}{l}\text { Half saturation coefficient for } \\
\text { acetate uptake }\left(\mathrm{kgCOD} / \mathrm{m}^{3}\right)\end{array}$ & 150 & 251 \\
\hline $\mathrm{Y}_{\mathrm{pro}}$ & $\begin{array}{l}\text { Propionate degraders yield on } \\
\text { substrate }\end{array}$ & 0.04 & 0.05 \\
\hline $\mathrm{Y}_{\mathrm{ac}}$ & $\begin{array}{l}\text { Acetate degraders yield on } \\
\text { substrate }\end{array}$ & 0.05 & 0.04 \\
\hline
\end{tabular}
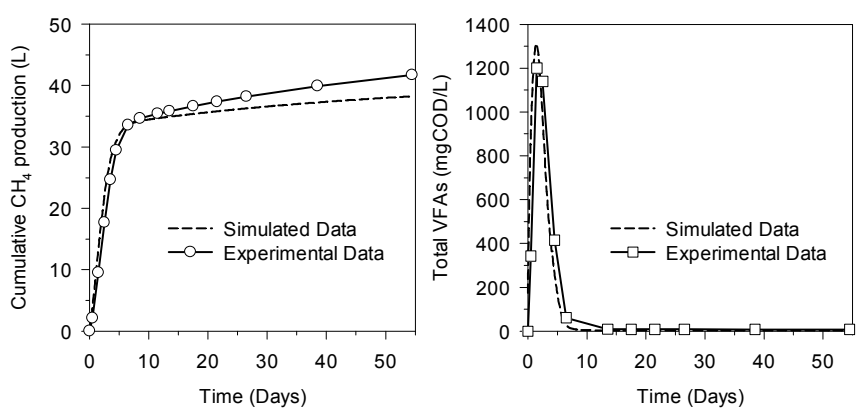

Fig. 1. Comparison of model simulated data with the experimental data of cumulative produced methane gas volume (left) and concentration profile of total VFAs (right).

Obtained results concerning the cumulative produced methane gas volume and the concentration profile of total VFAs were presented in Fig. 1. Total VFAs quickly disappeared in 6.5 days and methane gas was produced up until 55 days. As shown in Fig. 1, the simulation results with optimized parameters were in good agreement with the experimental data over all operation period. However, there was a slight difference for the cumulative produced methane gas volumes. Similar to the previous report [11], it was possible that the gas-liquid transfer and separation of methane gas took some time due to the high viscosity of sludge wastes, which would explain the time gap between methane gas production and VFAs utilization.

\section{CONCLUSION}

The present study focused on the anaerobic fermentative methane gas production from municipal sludge waste under thermophilic conditions. The application of ADM1 model to the obtained experimental data from the lab-scale batch methanogenic reactor for all operation period was successful. Therefore, the ADM1 could be a valuable tool for managing and process design of anaerobic digestion even in the case under thermophilic conditions.

\section{ACKNOWLEDGMENT}

This work was supported by the Green City Technology Flagship Program funded by the Korea Institute of Science and Technology (KIST-2013-2E23992).

\section{REFERENCES}

[1] J. Mata-Alvares, S. Macé, and P. Libres, "Anaerobic digestion of organic solid wastes. An overview of research achievements and perspectives" Bioresour. Technol., vol. 74, pp. 3-16, 2000.

[2] D. Bolzonella, L. Innocenti, P. Pavan, P. Traverso, and F. Cecchi, "Semi-dry thermophilic digestion of the organic fraction of municipal solid wastes: focusing on the start-up phase" Bioresour. Technol., vol. 86 , pp. 123-129, 2003.

[3] D.J. Batstone and J. Keller, "Industrial applications of the IWA anaerobic digestion model No. 1 (ADM1)" Water Sci. Technol., vol. 47, pp. 199-206, 2003.

[4] D.J. Batstone, J. Keller, I. Angelidaki, S.V. Kalyuzhnyi, S.G. Pavlostathis, A. Rozzi, W.T.M. Sanders, H. Siegrist, amd V.A. Vavilin, Anaerobic Digestion Model No. 1. International Water Association (IWA), Publishing, London, UK, 2002.

[5] F. Blumensaat and J. Keller, "Modelling of two-stage anaerobic digestion using the IWA anaerobic digestion model no. 1 (ADM1)" Water Res., vol. 39, pp. 171-183, 2005.

[6] J. Lauwers, L. Appels, I.P. Thompson, J. Degreve, J.F. Van Impe, and R. Dewil, "Mathematical modelling of anaerobic digestion of biomass and waste: Power and limitations" Prg. Energy Combust., vol. 39, pp. 383402, 2013.

[7] T.S.O. Souza, A. Carvajal, A. Donoso-Bravo, M. Pena, and F. FdzPolanco, "ADM1 calibration using BMP tests for modeling the effect of autohydrolysis pretreatment on the performance of continuous sludge digesters" Water Res., vol. 47, pp. 3244-3254, 2013.

[8] K. Derbal, M. Bencheikh-lehocine, F. Cecchi, A.-H. Meniai, and P. Pavan, "Application of the IWA ADM1 model to simulate anaerobic codigestion of organic waste with waste activated sludge in mesophilic condition" Bioresour. Technol., vol. 100, pp. 1539-1543, 2009.

[9] Y.H. Lee, Y.-C. Chung, and J.-Y. Jung, "Effects of chemical and enzymatic treatments on the hydrolysis of swine wastewater" Water Sci. Technol., vol. 58, pp. 1529-1534, 2008.

[10] J.A. Nelder and R. Mead, "A simplex method for function minimization" Comput. J., vol. 7, pp. 308-313, 1965.

[11] H.-S. Jeong, C.-W. Suh, J.-L. Lim, S.-H. Lee, and H.-S. Shin, “Analysis and application of ADM1 for anaerobic methane production" Bioprocess Biosyst. Eng., vol. 27, pp. 81-89, 2005. 


\section{Creative Commons Attribution License 4.0} (Attribution 4.0 International, CC BY 4.0)

This article is published under the terms of the Creative Commons Attribution License 4.0

https://creativecommons.org/licenses/by/4.0/deed.en US 